BIOKEMISTRI 17(2):143-147 (Dec 2005)

Available online at http://www.bioline.org. br/bk.

Abstracted online at www.ajol.info/journals/biokem

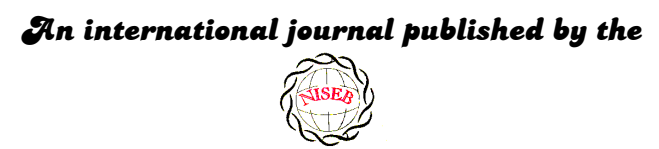

Tigerian \&ociety for \&ิxperimental \&iology

Printed in Nigeria

\title{
Enhancement of acetaminophen overdosage-induced hepatotoxicity by coconut water
}

\author{
Harrison U. NWANJO ${ }^{1}$, Emma A. NWOKORO ${ }^{1}$ and Okey A. OJIAKO ${ }^{2 *}$
}

1. Department of Medical Laboratory Sciences, Imo State University Owerri, Nigeria

2. Department of Biochemistry, Federal University of Technology, Owerri, Nigeria.

Received 5 June 2005

MS/No BKM/2005/028, (C) 2005 Nigerian Society for Experimental Biology. All rights reserved.

\begin{abstract}
Coconut water was investigated for its possible effect on the acetaminophen (paracetamol) overdosage-induced hepatotoxicity in three groups of albino Wistar rats. Administration of the minimum toxic dose of paracetamol $(150 \mathrm{mg} / \mathrm{kg}$ body weight) to animals (group II) produced significantly $(\mathrm{P} \leq 0.05)$ higher levels of alanine aminotransferase (ALT) and alkaline phosphatase (ALP) activities when compared to the control group (group I). There was however no significant $(\mathrm{P} \leq 0.05)$ aspartate aminotransferase $(\mathrm{AST})$ activity. Significantly $(\mathrm{p}<0.05)$ higher ALP and ALT activities were also observed in group III (the group administered with paracetamol and treated with coconut water) when compared with the control (group I) and the paracetamol-overdosed group (group II) indicating that the coconut water may have rather enhanced the toxicity of acetaminophen overdosage on the liver. The common use of coconut water as a palliative for drug overdosage is therefore contraindicated.
\end{abstract}

Key words: Acetaminophen overdosage, hepatotoxicity, coconut water.

*Author to whom all correspondence should be addressed.

E-mail: okeyojiako@yahoo.com; Tel: 08028254599 


\section{INTRODUCTION}

From the era of ancient man, there has always been interaction between man and his environment and this had led to the establishment of relationships. Such relationship could either be beneficial or detrimental. Man has been able to gain experiences that have helped him harness the benefits of such relationships as well as handle the negativities associated with it, among which are poisonous interactions like bites, stings, poisonous plants eaten as food etc, all of which result in disease. In a bid to find remedy, he has also always had to fall back on his immediate environment constituted largely by plants and plant products. The ancient man had little knowledge of the medicinal value of natural products, which he discovered by trial and error or by accidental observations of the discriminatory use of these plants by animals. Thus, by testing herbs, people began to acquire some rudimentary knowledge about medicine and pharmacology ${ }^{1}$. In West Africa, treatment has been provided by native doctors whose materia medica composed mainly of plants but sometimes involved animals and animal products $^{2}$.

Quite a number of plants have been explored as antitoxins. Among the Anglo-saxon herbalists of the $10^{\text {th }}$ Century, nettle (Urtica diordica) was used to counteract poisons and bites of dogs and bats. The seeds and flowers were also used for chills and fevers. In some parts of Africa, the decoction of the peeled branches of Spartium junceum (Spanish broom) was used as antidote against viper venom. Herbs like burdock, juniper, kelp, alfafa, dandelion, fennel and garlic also had widespread uses in counteracting metal poisoning. In traditional African practice, Allium cepa (onion) has been used to neutralize toxins resulting from scorpion stings. Modern science has proved the efficacy of many of the preparations used in ethnopharmacology and folk medicare. Pamplona-Roger ${ }^{3}$ for instance, has reported that onions stimulate metabolic and detoxification function of the liver. Morton ${ }^{4}$ reported the use of sugar made from the sap of Borassus palms (Arecaceae), a coconut-like fruit, to counteract poisoning in addition to its prescription in liver disorder.

Cocus nucifera (coconut) is traditionally recognised for its medicinal properties ${ }^{5}$ among several other uses ${ }^{6}$. The use of coconut water to counteract poisons is a common practice in Africa as well as India ${ }^{7}$. It has severally been used as an immediate remedy for drug overdosage. This study was thus designed to provide a scientific basis with which to validate the claims of this practice. It was also designed to investigate the safety of this practice by testing the effect of coconut water on the liver of patients who have taken overdose of paracetamol.

\section{MATERIALS AND METHODS}

\section{Animals}

Experimental animals (rats) were obtained from the Animal House of College of Medicine and Health Sciences, Imo State University, Owerri. Thirty albino Wistar strain rats of both sexes weighting $150-200 \mathrm{~g}$ were employed. The rats were randomly assigned into 3 groups of 10 rats each and housed in stainless steel cages and a twelve-hour light/dark cycle was maintained. They were allowed access to water and feed (product of Pfizer Nigeria Ltd.) ad libitum throughout the period of the experiment.

\section{MATERIALS}

Emzor brand of paracetamol syrup (Emzor Pharmaceutical Industries Ltd. Lagos, Nigeria) with $25 \mathrm{mg} / \mathrm{ml}$ concentration was purchased from a reputable Pharmacy in Owerri and used in the experiment. The minimal toxic single dose of paracetamol $(150 \mathrm{mg} / \mathrm{kg} \text { body weight })^{8,9}$ was prepared by measuring $0.60 \mathrm{ml}$ of $25 \mathrm{mg} / \mathrm{ml}$ paracetamol syrup $(30 \mathrm{mg} / 200 \mathrm{~g}$ body weight of rat). Ten green coconuts of various ages were harvested from different coconut trees in Ogwa, Mbaitoli Local Government area of Imo State. Botanical identity was kindly confirmed by Dr. S.E. Okeke, a taxonomist at the Department of Plant Science and Biotechnology, Imo State University. Voucher specimens were deposited in Imo State University, Owerri, Nigeria. The husks were peeled off. Prior to administration, 
the shell was cracked and the coconut water extracted into sterile containers.

\section{Experimental design}

The animals were separated into three groups of 10 animals each. Group I (control): Healthy animals not taking paracetamol or coconut; Group II: Animals administered $0.60 \mathrm{ml}$ of paracetamol syrup with $25 \mathrm{mg} / \mathrm{ml}$ concentration; Group III: Animals administered $0.60 \mathrm{ml}$ of $25 \mathrm{mg} / \mathrm{ml}$ paracetamol syrup and $1 \mathrm{ml}$ of coconut water after $10 \mathrm{~min}$ of drug administration. The paracetamol solution and the coconut water were administered orally using a syringe (without needle) inserted into the mouth of the rats and administered slowly to ensure that the measured volume is completely delivered.

\section{Laboratory assays}

The animals were sacrificed 24 hours after the drug administration and immediately $6 \mathrm{ml}$ of blood was collected and transferred into a centrifuge tube and allowed to clot for $30 \mathrm{~min}$ before centrifuging for $5 \mathrm{~min}$ using Wisperfuge model 1384 centrifuge (Tamson, Holland). The serum obtained after centrifugation was used for the estimation of liver enzymes. Alanine aminotransferase (ALT) and aspartate aminotransferase (AST) activities were assayed using the colorimetric method of Reitman and Frankel $^{10}$. Alkaline phosphatase was estimated using the colorimetric method of King and Armstrong ${ }^{11}$. All results were expressed as mean \pm standard deviation. The student's t-test was used to statistically analyze the results of the study.

\section{RESULTS AND DISCUSSION}

Table 1 shows the mean changes in the body weight before and after treatment. In all the groups, there was no significant $(\mathrm{P} \leq 0.05)$ change in the final body weight when compared with the initial body weight.

TABLE 1: Mean changes in body weight (grams) of rats before and after treatment and its significance

\begin{tabular}{|l|c|c|c|}
\hline Group & $\begin{array}{c}\text { Initial body } \\
\text { weight }(\mathbf{g})\end{array}$ & $\begin{array}{c}\text { Final body } \\
\text { weight }(\mathbf{g})\end{array}$ & Significance \\
\hline I (control) & $19.36 \pm 1.04$ & $19.48 \pm 1.04$ & $\mathrm{~N}$ \\
\hline II (paracetamol) & $19.40 \pm 1.04$ & $19.32 \pm 1.13$ & $\mathrm{~N}$ \\
\hline $\begin{array}{c}\text { III (paracetamol and } \\
\text { Coconut }\end{array}$ & $19.30 \pm 0.96$ & $18.95 \pm 2.0$ & $\mathrm{~N}$ \\
\hline
\end{tabular}

$N=$ not significant at $p>0.05$

TABLE 2: Changes in the activities of serum hepatic enzymes between individual groups.

\begin{tabular}{|l|l|l|l|}
\hline Groups & AST (iu/l) & ALT (iu/l) & ALP (iu/I) \\
\hline Group I (Control) & $66.0 \pm 5.00$ & $10.80 \pm 6.00$ & $115.50 \pm 10.10$ \\
\hline Group II & $70.40 \pm 9.50$ & $19.70 \pm 3.60^{*}$ & $145.50 \pm 15.00^{*}$ \\
\hline Group III & $68.50 \pm 8.96$ & $18.00 \pm 5.3^{*}$ & $218.80 \pm 19.78^{* *}$ \\
\hline
\end{tabular}

*Significantly different from the control $p<0.05 ; \quad * *$ Significantly different from the control and group II $(p<0.05)$. Results are expressed as mean $\pm S D$. 
Table 2 shows the mean values of the activities of serum hepatic enzymes in all the groups. In the analysis of the results, the mean ALT and ALP activities of $19.70 \pm 3.60 \mathrm{iu} / \mathrm{l}$ and 145.50 $\pm 15.00 \mathrm{iu} / 1$ respectively in the group II increased significantly when compared with the mean values of $10.80 \pm 6.00 \mathrm{iu} / \mathrm{l}$ and $115.50 \pm$ $10.10 \mathrm{iu} / \mathrm{l}$ for ALT and ALP in the control group. The increase in the mean value of AST activity in group II was not significant when compared with the control.

The mean activity of ALP in the group treated with coconut water significantly increased when compared to group II (i.e. group administered with paracetamol only) though the increase in the activity of ALT in group III was only significant when compared with the control showing that the administered coconut water had no beneficial effect with respect to this diagnostic enzyme.

Results obtained from this study further affirm the toxicity of acetaminophen (paracetamol) in high doses with an elevation in a key hepatotoxicity diagnostic parameter (ALT) occurring more in the group administered with high dose of paracetamol only and another elevation in a major diagnostic parameter (ALP) occurring more in the group treated with paracetamol and coconut water. A more significant increase in ALT and ALP activity relative to AST conforms to the usual pattern of increase in the activities of cytoplasmic enzymes as against mitochondrial enzymes. This pattern is characteristic of cell damage resulting from drug toxicity ${ }^{12}$.

Contrary to general notion however, coconut water treatment seemed to amplify the hepatoxicity of acetaminophen. This is shown by a highly significant $(\mathrm{p}<0.01)$ increase in ALP activity relative to the control and even the group treated with an overdose of paracetamol. The liver source of this enzyme is confirmed by a modestly elevated AST activity and suggests bile duct involvement and liver injury ${ }^{13}$. This finding is in consonance with the report of the Coconut Development Board of India ${ }^{14}$, that coconut water aids the absorption of drugs via its electrolyte effect. It is logical therefore, to infer that an enhanced drug absorption in a case of overdosage would invariably increase the serum level of the active metabolite of the toxic drug (like acetaminophen in this case) and consequently result in increased cell damage caused by the metabolite. Coconut water appears to have achieved this. But this is not in conformity with the principle of limiting drug absorption employed in cases of overdosage ${ }^{9}$ which coconut water is intended to achieve.

Furthermore, findings from this study seem to agree with report by Hojo et $a l,{ }^{15}$ on hepatotoxicity in rats, of acetaminophen and $\mathrm{N}$ acetyl-p-benzoquinoneimine (NABQI) and the enhancement of their hepatotoxicity by fructose. They demonstrated that sucrose (and fructose) exerted a synergistic effect on acetaminophen toxicity in rats having observed a 20 -fold increase in ALT and SDGH (Sorbitol dehydrogenase) activities with co-administration of $400 \mathrm{mg} / \mathrm{kg}$ acetaminophen and $1.8-3.4 \mathrm{~g} / \mathrm{kg}$ sucrose relative to the activities obtained when acetaminophen was administered alone. Coadministration of glucose or fructose as well as sucrose elevated acetaminophen-induced hepatotoxicity parameters in rats. These results, together with their allopurinol-inhibition experiment informed their suggestion of the involvement of high dose sucrose at a step/steps occurring after the metabolic activation of acetaminophen. Coconut water treatment may also have followed the same mechanism in accentuating rather than mitigating hepatotoxicity arising from an overdosage of acetaminophen.

In concluding therefore, we posit that coconut water does not actually have any protective effect on the liver against toxicity of paracetamol overdosage. Rather, it could enhance the hepatotoxic effect of paracetamol overdosage. The practice of administering coconut water immediately following known or accidental poisoning by paracetamol may therefore be said to be an erroneous practice which should be discouraged. We recommend that more verification be done and the results of such findings be given wider publicity in order to educate people on the potential dangers of such improper therapeutic practice. This is 
particularly important in the rural areas of Nigeria where this practice is rampant. It is hoped that the findings of this study would pave way for further research possibilities on the therapeutic uses of coconut water owing to its availability.

\section{REFERENCES}

1. Wakang, F. U. (1985) Traditional Chinese Medicine and Pharmacology. $1^{\text {st }}$ Ed. Foreign Language Press Beijing. pp 1014.

2. Oliver-Bever, BEP (1986) Medicinal Plants in Tropical West Africa. Cambridge University Press, Cambridge, p. 3.

3. Pamplona-Roger, G. O. (2001) Encyclopaedia of Medicinal Plants. Editorial Safeliz

4. Morton, J. F. (1988) Notes on distribution, propagation and products of borassus palms (Arecaceae). Econ. Bot. 42:420441.

5. Bosch, C.H., Simeonsma, J.S., Lemmens, R.H.M.J. and Oyen L.P.A. (eds.) (2002) Plant Resources of Tropical Africa: Basic lists of species and commodity grouping, Prota Programme, Wageningen

6. Bokhari, M.H. and Ahmed, Ch.M.S. (1980) Food Plants of Borno State, Nigeria. Ghulam Publishers, Lahore, p.14.

7. Biplab, D., Sabita, P. D., Bhattacharjee, P. R. and Goswami, B. B. (2002) Coconut:
The tree of life. Ind. J. Pharm. Educ. 16:23-30.

8. Prescott, L. F. (1983) Paracetamol overdosage, pharmacological considerations and clinical management. Drugs 25:290-314.

9. Laurence, D. R., Bennett, P. N. and Brown, M. J. (1999) Clinical pharmacology. Churchill Livingstone, London. pp. 139140.

10. Reitman, S. and Frankel, S. (1957) A colorimetric method for the determination of SGPT and SGOT, Am. J. Clin. Path. 25:56-62.

11. King, E.J. and Armstrong, A.R. (1934) A convenient method for determining serum and bile phosphatase activity. Canadian Med. Assoc. J. 31:376-381.

12. Zilva, F. J. and Pannal, P. R. (1984) Clinical Chemistry in Diagnosis and Treatment. $4^{\text {th }}$ edn. Lloyd-Luke London. pp 318-319.

13. Tietz, N. W., (1976) Clinical Guide to Laboratory Tests. W. B., Saunders Company, Philadelphia. pp. 7-8,

14. Coconut Development Board, India. (2000) Coconut Products: Tender coconut water. http://www.coconutboard.nic.in

15. Hojo, M., Hanoika, K., Miyata, M., Yamazoe, Y. (2000) Hepatotoxicity of acetam- inophen and N-acetyl-pbenzoquinoneimine (NABQI) and enhancement by fructose. Xenobiotica: 30:933-941. 